Forum is a section for free discussion of critical ideas about current paradigms of tropical science. Like other sections in the journal, Forum does not necessarily represent the opinions of the editorial and scientific boards. Unsolicited replies will be considered for publication on the basis of quality and pertinence.

\title{
Biocompatibility: a Criterion for Conservation
}

\author{
Alexander F. Skutch ${ }^{1}$ \\ 1 Quizarrá 8000-939, San Isidro de El General, Costa Rica.
}

Received 26-IX-1997. Corrected 15-IV-1998. Accepted 29-IV-1998.

\begin{abstract}
A rich ecosystem like a tropical rain forest contains three categories of organisms: (1) the sustainer green photosynthetic plants of all growth forms, their pollinators, seed dispersers, and protectors from injurious insects, and mostly obscure decomposers of dead matter that replenish the soil's fertility; (2) the associates or "guests", a diverse group that appears to be neither necessary for the maintenance of the ecosystem nor injurious to it; and (3) the "enemies", predators great and small, parasites external and internal, pathogens, etc. that torture, mutilate, or destroy members of the first two categories, which coexist harmoniously, rarely injuring one another. I urge conservationists to give preferential treatment to these compatible categories, ceasing to apply inadequate resources to the protection or increase of members of the third category, if nor trying to eliminate some of them. By promoting biocompatibility, or compatible biodiversity, instead of biodiversity of undefined limits, we might make a more harmonious, productive, and enjoyable natural world.
\end{abstract}

Key words: Conservation, biocompatibility or compatible biodiversity, harmony.

Many yeas ago, I established a homestead beside a large tract of tropical rain torest, in a region still wild. Around my new dwelling, I planted trees and shrubs with colorful flowers to provide nectar and berries for birds, and daily placed bananas for them on a board in a tree. Soon many, from the adjoining woodland and surrounding open country, nested around my house. With one troublesome exception, the Piratic Flycatcher (Legatus leucophaius), which stole nests built by other birds, all dwelt peacefully together, singing their songs and rearing their young. But predators, chiefly snakes, small mammals, and an occasional raptor, invaded the garden to plunder nests or capture adults.

What should I do about this distressing situation? I believed that I owed protection to the birds that I encouraged to nest near me. After much thought, I adopted the principle of harmonious association. I would do all that I could to protect the birds and other animals that dwelt harmoniously together, taking measures to remove those that disrupted this concord. For the neighboring forest, I preferred the principle of laissez faire, or refraining from interfering with nature. Although the situation there, where predators were numerous, was not ideal, it appear $d$ too big and complex to be controlled by me, or by anyone.

Today, half a century later, humans have increased so greatly, and made their presence felt so widely, that the situation nearly everywhere is becoming more like that in farms and gardens than in wild, undisturbed woodland. During the same interval, the conservation 
movement has grown much stronger, notably in tropical countries where it was weak. Other than that all true conservationists try to preserve some part of nature, and general agreement that the protection of habitats is indispensable, a wide diversity of preferences is evident among them. Some are more concerned about forests, others about wetlands or the oceans. Some are interested mainly in a certain group of animals birds or bats or amphibians. Some try to increase raptorial birds, while others deplore the decline of birds on which the raptors prey. These divergent aims sometimes clash, with the consequent waste of effort and of the inadequate funds available for the protection of nature. We must clarify our aims; we need a comprehensive goal for conservation.

As a guiding principle for conservation, the following alternatives might be considered. We should endeavor to promote: (1) maximum diversity, or number of species in all categories; (2) the maximum sustainable number of individual organisms; (3) those elements of the natural world that contribute most to human prosperity and happiness, or are at least no threat to these ends. Let us examine them in this order.

(1)- "Biodiversity", a neologism, has become the rallying cry of conservationists. That without biodiversity, and a great deal of it, we could not survive is a truth too obvious to educated people to need elaboration. We need plants to produce food; insects, birds, and other creatures to pollinate their flowers; fungi and bacteria to decompose dead tissues and return their fertilizing components to the soil; and much else. Recent explorations of the canopy of tropical forests have revealed that the number of extant species is much greater than we had supposed only a few decades ago and may run into millions.

Biodiversity has certainly become excessive, and is responsible for a major part of the sufferings of animals, including humans. In addition to all predators that strike down the living victims and too often begin to tear them apart before they die, an immense diversity of parasites torture, debilitate, and kill their hosts. Since many multicellular animals appear to be infected by several kinds of parasites, internal and external, many of which are restricted to a single species or closely related group, it is probable that parasites far exceed, in number of species and individuals, all other organisms. Moreover, they can weaken and kill plants, or ravage whole forests. Undoubtedly, a great reduction of biodiversity, probably 50 percent or more, would make life much more pleasant not only for humans but for many other creatures.

Although we hear much about biodiversity, I am not aware of any wide consesus as to its desirable limits. Should we approve its absolute maximum, which would include all parasites, pathogens, and predators, or should we be more discriminating? I doubt that many advocates of biodiversity would oppose the extermination of organisms responsible for human diseases, or of the blood-sucking insects that spread diseases and can make life miserable for many kinds of animals. In regard to larger predators, the situation is confused. Many friends of animals would welcome the great reduction, if not extinction, of venomous and nest-robbing snakes, voracious alligators, the fiercer raptors, or the most dangerous sharks. If conservationists could agree on the desirable limits of biodiversity, cooperation and efficiency might increase.

(2)- Instead of promoting biodiversity absolutely of within certain well-defined limits, we might make our goal the maximum number of individuals, of all kinds or of certain specified kinds, within Earth's capacity to support them indefinitely in a flourishing state. Some humanitarian philosophers, like Tom Regan ${ }^{1}$, maintain that every member of a thriving species has no less claim to protection than have the few surviving individuals of a vanishing species. Only individuals may enjoy and suffer; lacking organic unity, a species as a whole cannot feel.

(3)- Widespread is the belief that we should protect the natural world, not for its own sake, but for its importance to humankind. Vegetable and animal species favorable to human interests should receive preferential treatment; others, 
useless or harmful to humans, might be neglected or extirpated. If we adopt this view, we should remember that organisms which do not directly contribute to human welfare are often necessary for the ecological health of the biotic community in which useful species thrive; as, for example, mycorrhizal fungi, that envelop the finer roots of forest trees and help them absorb nutrients from the soil, of no direct use to man, contribute to the maintenance of forests where timber trees thrive. Moreover, we should not forget that nature is rich in aesthetic and intellectual as well as economic values, which unfortunately sometimes conflict. A land that yields a maximum of food, fibers, and other salable products might become so monotonous and uninteresting, so poor in aesthetic appeal, that our spirits would droop while we contemplate it. Narrow concentration on the welfare of humankind might soon prove harmful to humans.

As an approach to conservation less daunting than biodiversity of indefinite compass, I suggest that we devote our efforts to promoting biocompatibility, or compatible biodiversity, the harmonious association of diverse species. To start a program for biocompatibility we might choose a large community of diverse creatures that coexist without destructive strife, or better, with mutual support, then include whatever other organisms might be compatible with this nuclear group. An appropriate association is that of flowering plants, their pollinators, and the dispersers of their needs. Such a community of reciprocally helpful plants and animals includes plants of many families and growth forms, from herbs and vines to towering trees; among their pollinators are bees, butterflies, moths, beetles, flies and (in the New World) hummingbirds and certain tanagers; the disseminators are a multitude of frugivorous birds, bats, and fligthless mammals, including the widespread, terrestrial agoutis of tropical America. Plants attract their pollinators by their colors and fragrance, reward them with nectar and excess pollen. With eagerly sought fruits and rillate seeds, they reward animals who digest only the soft pulp and spread viable seeds far and wide.
To injure the organism with which it exchanges benefits would not advantage any member of this association; only exceptionally do some break the unwritten "contract" by stealing nectar from flowers without pollinating them, as hummingbirds and bees occasionally do. Frugivorous birds rarely harm one another; the only exceptions to this rule in tropical American forests known to me are the greatbilled toucans, who swallow fruits and disseminate seeds too big for smaller birds in this guild, but they too frequently plunder the nests of lesser birds. Bees occasionally raid the hives of different species, stubbornly fighting the residents and, if victorious, carrying off their stores of nectar and pollen. Like most things in this perplexing world, the plant-pollinator-disperser association is not perfect; nevertheless, one of evolution's most admirable achievements, contributing immensely to nature's h rmony and productivity and, especially by flowers, birds, and butterflies, to its beauty. Moreover, directly or indirectly, the association provides nourishment for a large proportion of terrestrial life.

To learn how many species belong to the plant-pollinator-disperser association in any area might require a prolonged study by a team of botanists, ornithologists, and entomologists, which to my knowledge has never anywhere been done. I surmise that in a tract of temperature-zone woodland the association would include hundreds of species. In a similar area of tropical rain forest, where wind-pollination is much rarer than in the temperate zones and more winged pollinators are needed, the association might run into thousands. Around this nucleus cluster other species that are neither pollinators nor dispersers. Among them are insectivorous birds and other creatures that coexist harmoniously with the dispersers and are indeed indispensable to them, for without the former, insects might devour all the foliage and kill the plants that yield the fruits and nectar.

Less closely allied to the plant-pollinatordisperser guild is a diversity of animals that apparently neither help support the ecosystem nor adversely affect it. For lack of a better name 
we might call them "guests". In tropical American forests they include tinamous, antthrushes, quails, some pigeons, and among raptors, the Laughing Falcon, Herpetotheres cachinnans that subsists almost wholly upon snakes. Parrots that digest seeds instead of the pulp that envelopes them appear not to reduce the reproduction of trees and they live harmoniously with other birds. Among mammals, armadillos, anteaters, sloths, some primates, and others also belong to the biocompatible community.

Similar biocompatible associations are found in wetlands, prairies, arctic tundras, and the oceans, but apparently have not been studied from this point of view. Probably they include fewer collaborators than those of woodlands. In the oceans, where the biomass of animals is very much greater, in relation to that of the chlorophyll-bearing plants that support them, the struggle for survival is fiercer and predation more rife, a truth to which the huge production of eggs of many marine creatures, far exceeding that of any terrestrial animals except possibly queen termites and bees, bears unimpeachable testimony. Nevertheless, in the oceans biocompatible associations do occur, notably of cleaner fishes and their clients.

Preferential treatment of biocompatible organisms would benefit the indispensable sustainers of terrestrial life but certainly not everything. It would protect neither invertebrate parasites nor parasitic cockoos and cowbirds, all of which are only a froth (although sometimes a smothering one) on the surface of the living world. Whenever they seriously threaten human life or economic interests, vigorous, often costly efforts are made to exterminate them. Predatory vertebrates, especially among mammals and birds, present special problems. Mostly solitary, unsocial creatures, they do not fit into any biocompatible association. Because many of them are big and powerful, they frequently excite humans' misplaced admiration of bigness and power (a major cause of man's misfortunes) and not a few win admiration by gracefulness or beauty. Contributing little or nothing to the support of the living community (except its scavengers), they make heavy demands upon it. A conservation program committed to biocompatibility rather than undefinded biodiversity should, if not delibertely try to reduce their numbers, at least stop spending all the money and effort now given to their protection and increase.

One of the gravest mistakes of wildlife management in our time is the re-introduction of predatory birds and mammals into areas where they have long been absent, such as the artificial establishment of Peregrine Falcons (Falco peregrinus) in cities. The undesirable, often disastrous, effects of introducing alien animals, even some admirable in themselves, in Australia, New Zealand, and the United States, have long been recognized and deplored. The re-introduction of large and dangerous species may become equally deplorable.

Predation is widely viewed as indispensable to prevent populations of animals becoming so numerous that they destroy their habitats, "eating themselves out of house and home". Even those who condemn predation as a major evil, a lamentable miscarriage of evolution, may grudgingly concede that it is a necessary evil. Nevertheless, the role of predation in regulating animal populations has been exaggerated. It is most obviously necessary in the case of large grazing and browsing quadrupeds -deer, antelopes, elephants, and the like- which may so severely overexploit grassland or light woodland that it may need years to recover after their exploiters reduce their number by starvation. Where elephants are protected, they become too abundant, and so damage their range that, despite sentiment, their herds must be culled to avert disaster. Shooting excess individuals of any species by expert marksmen is less harsh than the methods of predators, which too often begin to devour still living victims.

When we turn to the frugivorous and insectivorous birds, we find a very different situation. It is hardly an exaggeration to say that they are incapable of ruining their habitats. In an unfavorable season fruits may become so scarce that hungry birds are reduced to eating them before they ripen, when they are harder to 
digest and less nourishing but may already contain viable seeds. The birds' reproduction may be depressed, and some may starve; but the fruiting trees and shrubs will not be injured by the premature removal of their fruits, and next year they may yield abundantly. Similarly, nectar-drinkers can hardly injure flowering plants, even if, as sometimes happens, they damage flowers by piercing or tearing corollas to reach the sweet fluid. When nectar is scarce, they may turn to insects, as hummingbirds frequently do. Insectivorous birds can rarely glean so effectively that they exterminate the insects, spiders, or other small invertebrates that nourish them. With their rapid reproduction and reduced pressure upon them, they soon restore their populations and continue to support the insectivores.

Birds can regulate their populations without outside intervention. A widespread method is territoriality, which adjusts the number of breeding pairs to the areas and resources adequate for rearing their broods. The size of broods is correlated with the longevity of adults. At latitudes where the rigors of winters, or the hazards of long migrations to escape them, reduce life expectancy, broods are substantially larger than those of related species at low latitudes where the average life span of resident birds is considerably longer. In contrast to mammals, who often begin to reproduce before they cease growing, many birds delay breeding for one or more years after they are full-grown. Extreme examples of this are long-lived marine birds, some of which do not breed until they are five to ten years old, and they may lay only one egg, as among albatrosses.

"Pest birds", like Red-billed Queleas (Quelea quelea) in Africa and Eared Doves (Zenaida auriculata) in Argentina, appear to contradict the foregoing statements by building up excessive populations that devour field crops, especially grains. They live in artificial situations. Farmers unintentionally help them multiply, then complain when the birds take advantage of agricultural bounty. Predators fail to reduce the teeming populations of these birds enough to save the crops. Thus, we might say, with reference to birds, that predators are either unnecessary to control populations or are ineffective. The same appears to be true of many other kinds of animals, but to discuss this matter here would lead us too far astray.

After this disgression that seemed necessary to counter certain objections to a conservation program that would exclude from protection, if not try to exterminate, some of the most predatory vertebrates, let us return to the benefits of promoting biocompatibility instead of unlimited biodiversity. In the first place, it would help to preserve the maximum sustainable number of individuals of the protected, nonpredatory or mildly predatory species, which are usually more numerous than the animals that prey upon them (our second alternative). In particular, it would help to retard the widely lamented decline of many species of birds, especially Neotropical migrants. Predation is only one of several causes of their plight, but it is by no means negligible; raptors take a heavy toll of migrants, especially when they are concentrated at their staging places, where they interrupt their journeys to replenish their depleted reserves of energy.

By safeguarding the extremely important plant-pollinator-disperser association and its allies, the promotion of biocompatibility would conduce greatly to human economic interests (our third alternative). It would make close association with nature more rewarding and pleasant to the growing number of people who enjoy the majesty of trees and the beauty of flowers and birds and are distressed or repelled by the sight of predators striking down or tearing their victims and the hideously mangled remains of what yesterday was a beautiful animal going peacefully about its business and enjoying its life. By no conceivable effort could conservationists, however numerous and well funded they became, bring perfect harmony into the living world, but by their united efforts they might bring it a little closer to the realization of this widespread, ancient, and perennially attractive ideal.

As the forces of destruction increase and their weapons become more devastating, conservationists wage a losing war. It is time to 
reconsider our strategy. As currently practiced, biodiversity is unselective, supporting both our allies and our enemies in our major endeavor, the preservation of ecosystems. When we analyze an ecosystem, we find it an association of organisms that in diverse ways mutually support one another, as in the plant-pollinator-disperser alliance, thereby making and preserving the system, with a large admixture of organisms hostile to these key members of the system. The former support our efforts to preserve forests and other ecosystems, the latter oppose our efforts. Instead of maintaining an essentially neutral attitude toward the protagonists in the internal struggle that afflicts habitats, we should throw our weight on the side of defenders, giving them preferential treatment and whatever aid we can, perhaps not trying to exterminate all their foes -in any case an endeavor that, if successful, might have unforeseen and undesirable side effects -but at least not supporting the enemies. If humans could make ourselves more compatible with biocompatible associations that support the natural world, we might form an alliance that would indefinitely preserve a friendlier, more peaceful ambience.

1 Regan, T. 1983. The case for anomal rights. University of Califomia Press, Berkeley and Los Angeles. 425 p. 